\title{
Effects of High-Fat Diets Containing Different Fats on Cholesterol Metabolism in Starvation-Refeeding Rats
}

\author{
Reiko Inai ${ }^{1}$, Tatsuhiro Matsuo ${ }^{2 *}$ \\ ${ }^{1}$ Department of Health and Nutritional Science, Nagoya Keizai University, Aichi, Japan; ${ }^{2}$ Faculty of Agriculture, Kagawa University, \\ Kagawa, Japan. \\ *Email: matsuo@ag.kagawa-u.ac.jp \\ Received June $18^{\text {th }}, 2011$; revised July $12^{\text {th }}, 2011$; accepted July $19^{\text {th }}, 2011$.
}

\begin{abstract}
The present study was performed to investegate the effects of high-fat diets containing different fats on cholesterol metabolism in starvation-refeeding rats. Forty female Donryu rats were divided into two groups and then fed high-fat diets containing beef tallow or corn oil without cholesterol for 14 days. Then, 10 rats from each group were divided into high-cholesterol and cholesterol-free groups (Experiment 1). Another 10 rats from beef tallow and corn oil groups were divided into high-cholesterol and high-cholesterol-cholestyramine groups (Experiment 2). All rats were fasted for 2 days followed by 3 days of feeding. In Experiment 1, the high-cholesterol diet caused significant increases in plasma total cholesterol and cholesteryl ester concentrations in the beef tallow diet group. In Experiment 2, dietary cholestyramine markedly decreased plasma and liver cholesterol levels; however, these cholesterol levels were higher in the beef tallow diet group even if cholestyramine was added to the diet. These results suggested that the cholesterollowering effect of dietary corn oil may not be due solely to reabsorption of bile acids. This study suggested that high-fat diets containing different fats affected cholesterol metabolism under conditions of starvation-refeeding.
\end{abstract}

Keywords: Starvation-Refeeding, Cholesterol Metabolism, Beef Tallow, Corn Oil, Cholestyramine

\section{Introduction}

It is well established that starvation followed by refeeding (starvation-refeeding) causes an increase in mammalian hepatic lipogenesis (de novo synthesis of longchain fatty acids) in comparison to the levels obtained with the same diet fed ad libitum [1-7]. The magnitude of the increase is dependent on the diet composition and the species, age, and sex of the animals [8-10]. The changes in lipogenic enzyme activity are considered to be due to an alteration in the rate of enzyme protein synthesis as a consequence of increased cellular concentration of specific mRNAs [11-13].

Cholesterol, a physiologically significant lipid, as well as triacylglycerol (TG) or fatty acids, is present in tissues and in plasma lipoprotein either as free cholesterol or, in combination with long-chain fatty acids, as cholesteryl ester [14]. It is synthesized in many tissues from acetyl-CoA and is ultimately eliminated from the body in the bile as cholesterol or bile salts. Cholesterol is the precur- sor of all other steroids in the body, such as glucocorticoid and sex hormones [14]. Cholesterol synthesis in the liver may be accelerated under conditions of activated hepatic lipogenesis because cholesterol and fatty acids are closely related to mammalian lipid metabolism [15].

Recently, we suggested that starvation-refeeding activated cholesterol metabolism in rats fed a high-cholesterol-unsaturated fat diet [16]. On the other hand, many studies have dealt with the effects of feeding with dietary fats of different fatty acid compositions on cholesterol metabolism [17-21]. It was suggested that saturated fatty acids caused hypercholesterolemia, both in humans and in animal models [17-21]. However, it is unclear whether a saturated fat diet increases serum and liver cholesterol levels under starvation-refeeding conditions. In the present study, we investigated the effects of high-fat diets containing different fats on cholesterol metabolism in starvation-refeeding rats. Furthermore, we examined the effects of cholestyramine, a resin that strongly binds bile acids, on serum and liver cholesterol levels under starve- 
tion-refeeding conditions

\section{Materials and Methods}

All procedures involving rats were approved by the Experimental Animal Care Committee of Kagawa University.

\subsection{Experiment 1: Effects of Dietary Fats and Cholesterol on Cholesterol Metabolism in Rats under Starvation-Refeeding Conditions}

\subsubsection{Animals, Diets, and Experimental Design}

Twenty female Donryu rats (age 4 weeks) were purchased from Japan SLC, Inc. (Shizuoka, Japan). Half of the animals were fed a beef tallow diet, and the other half were fed a corn oil diet. All rats were housed individually at $22^{\circ} \mathrm{C} \pm 1{ }^{\circ} \mathrm{C}$ with lights on from $08: 00$ to $20: 00 \mathrm{~h}$ and free access to water. The rats were fed CE-2, a commercial rodent diet (CLEA, Tokyo, Japan) ad libitum until 5 weeks of age. The fatty acid compositions of test lipids are shown in Table 1. The rats were fed two synthetic high-fat diets containing different fats without cholesterol (Table 2). This diet also contained (per kilogram): retinyl palmitate, 60,000IU; ergocalciferol, 600IU; $\alpha$ tocopheryl acetate, $1 \mathrm{~g}$. The vitamin and mineral mixtures [22] were purchased from Oriental Yeast Co., Ltd. (Tokyo, Japan). After a 14 day feeding period, the rats were divided into two sub-groups (Figure 1).

Half of each of these groups was fed the experimental diet (cholesterol-free diet, Con), and the other half was fed a diet to which $1 \%$ cholesterol and $0.25 \%$ bile powder were added (high-cholesterol diet, Chol). All groups were fasted for 2 days followed by 3 days of refeeding.

Table 1. Fatty acid composition of experimental fats.

\begin{tabular}{ccc}
\hline \multirow{2}{*}{ Fatty acid $^{*}$} & Beef tallow & Corn oil \\
\cline { 2 - 3 } & \multicolumn{2}{c}{$\mathrm{g} / 100 \mathrm{~g}$ total fatty acid } \\
\hline $14: 0$ & 1.4 & Trace \\
$16: 0$ & 25.1 & 9.9 \\
$16: 1$ & 3.1 & 0.1 \\
$18: 0$ & 18.5 & 2.1 \\
$18: 1$ & 44.9 & 29.4 \\
$18: 2$ & 3.5 & 53.6 \\
$20: 0$ & 0.2 & 1.0 \\
$20: 1$ & 0.6 & 0.5 \\
$20: 4$ & Trace & Trace \\
$22: 6$ & 0.4 & 0.8 \\
\hline
\end{tabular}

"Number of Catoms: number of double bonds.

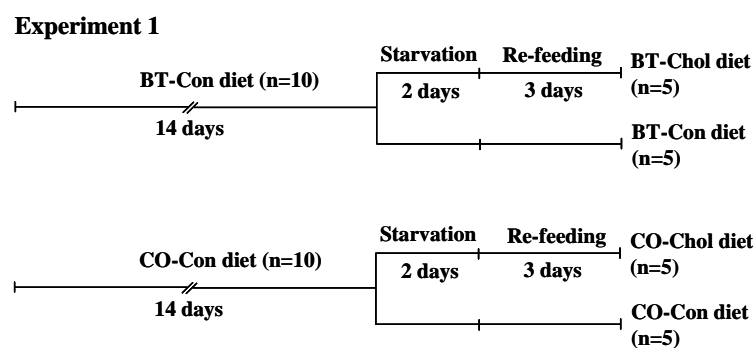

Experiment 2
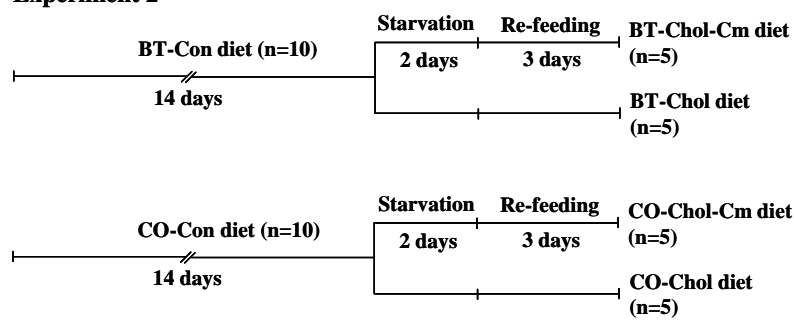

Figure 1. Experimental design in this study. BT, beef tallow; CO, corn oil; Con, control; Chol, cholesterol; Cm, cholestylamine.

After the starvation-refeeding period, the rats were killed by cardiac puncture under anesthesia. Blood was collected to obtain plasma, and the liver was quickly removed, weighed, and stored at $-40^{\circ} \mathrm{C}$.

\subsubsection{Analysis}

The plasma total cholesterol, free cholesterol, HDL cholesterol, and TG concentrations were determined using commercial kits (Cholesterol E-Test, Free Cholesterol E-Test, HDL-Cholesterol E-Test and Triglyceride E-Test, Wako Pure Chemical Industries, Osaka, Japan). Plasma cholesteryl ester concentration was calculated from the plasma total cholesterol and free cholesterol concentrations. Total liver lipid and plasma lipid were extracted by the method of Folch et al. [23].

Liver total cholesterol, free cholesterol, and cholesteryl ester contents were determined by the method described previously $[24,25]$. Plasma cholesteryl ester was detemined using a thin-layer chromatography technique [26]. The fatty acid composition of plasma cholesteryl ester was determined using gas chromatography. The TG extract liquid was vaporized by nitrogen gas and then transmethylated using methanol-sulfuric acid (230:2, v/v). The fatty acid methyl esters were extracted with hexane and separated in a gas chromatograph (ModelG-163; Hitachi Co., Tokyo, Japan) equipped with a $3 \mathrm{~mm} \times 2 \mathrm{~m}$ glass column filled with packing material (EGSS-Y; Shinwa Chemical Industries, Ltd., Tokyo, Japan). The column temperature was set at $187^{\circ} \mathrm{C}$. The carrier gas was helium at a flow rate of $40 \mathrm{ml} / \mathrm{min}$. Methyl esters of individual fatty acids were identified in the chromatograms by comparing their retention times to those of 
Table 2. Composition of experimental diets.

\begin{tabular}{|c|c|c|c|c|c|c|c|c|}
\hline \multirow[b]{3}{*}{ Ingredients } & \multicolumn{4}{|c|}{ Experiment 1} & \multicolumn{4}{|c|}{ Experiment 2} \\
\hline & \multicolumn{2}{|c|}{ Beef tallow } & \multicolumn{2}{|c|}{ Corn oil } & \multicolumn{2}{|c|}{ Beef tallow } & \multicolumn{2}{|c|}{ Corn oil } \\
\hline & Chol & Con & Chol & Con & Chol-Cm & Chol & Chol-Cm & Chol \\
\hline & \multicolumn{8}{|c|}{$\mathrm{g} / \mathrm{kg}$ diet } \\
\hline Casein & 250.0 & 250.0 & 250.0 & 250.0 & 250.0 & 250.0 & 250.0 & 250.0 \\
\hline$\alpha$-Starch & 427.5 & 440.0 & 427.5 & 440.0 & 407.5 & 427.5 & 407.5 & 427.5 \\
\hline Beef tallow & 200.0 & 200.0 & - & - & 200.0 & 200.0 & - & - \\
\hline Corn oil & - & - & 200.0 & 200.0 & - & - & 200.0 & 200.0 \\
\hline Mineral mixture* & 50.0 & 50.0 & 50.0 & 50.0 & 50.0 & 50.0 & 50.0 & 50.0 \\
\hline Vitamin Mixture* & 8.5 & 8.5 & 8.5 & 8.5 & 8.5 & 8.5 & 8.5 & 8.5 \\
\hline Cellulose & 50.0 & 50.0 & 50.0 & 50.0 & 50.0 & 50.0 & 50.0 & 50.0 \\
\hline Choline chloride & 1.5 & 1.5 & 1.5 & 1.5 & 1.5 & 1.5 & 1.5 & 1.5 \\
\hline Cholesterol & 10.0 & - & 10.0 & - & 10.0 & 10.0 & 10.0 & 10.0 \\
\hline Bile powder & 2.5 & - & 2.5 & - & 2.5 & 2.5 & 2.5 & 2.5 \\
\hline Cholestyramine & - & - & - & - & 20.0 & - & 20.0 & - \\
\hline
\end{tabular}

These diets contained (per kilogram): retinyl palmitate, 60,000IU; ergocalciferol, 600IU; a-tocopheryl acetate, 1 g. Con, control; Chol, cholesterol; Cm, cholestyramine. "Harper's mixture.

pure methyl esters, and were quantified by comparing the areas under their peaks.

\subsection{Experiment 2: Effects of Dietary Fats and Cholestyramine on Cholesterol Metabolism in Rats under Starvation-Refeeding Conditions}

\subsubsection{Animals, Diets, and Experimental Design}

Twenty female Donryu rats (age 4 weeks) were purchased from Japan SLC, Inc. (Shizuoka, Japan). Half of the animals were fed a beef tallow diet, and the other half were fed a corn oil diet. All rats were housed individually at $22^{\circ} \mathrm{C} \pm 1{ }^{\circ} \mathrm{C}$ with light on from 08:00 to 20:00 $\mathrm{h}$ and free access to water. The rats were fed CE-2, a commercial rodent diet (CLEA) ad libitum until 5 weeks of age. Then, the rats were fed a beef tallow diet or a corn oil diet without cholesterol (Con diet, Experiment 1) ad libitum for 14 days. After a 14 day feeding period, the beef tal- low and corn oil groups were divided into two subgroups (Figure 1). Half of each of these groups was fed a diet to which $1 \%$ cholesterol and $0.25 \%$ bile powder were added (high-cholesterol diet, Chol), and the other half was fed the Chol diet to which $2 \%$ cholestyramine was added (high-cholesterol-cholestyramine diet, Chol$\mathrm{Cm}$ ). The compositions of experimental diets are shown in Table 2. All groups were fasted for 2 days followed by 3 days of refeeding. After the starvation-refeeding period, the rats were killed by cardiac puncture under anesthesia. Blood was collected to obtain plasma, and the liver was quickly removed, weighed, and stored at $-40^{\circ} \mathrm{C}$.

\subsubsection{Analysis}

The plasma substrates, liver lipids, and fatty acid composition of plasma cholesteryl ester were assayed as in Experiment 1 .

\subsection{Statistical Analysis}

The values are expressed as means \pm standard deviation (SD). Data were evaluated by two-way ANOVA and Turkey's test was used to determine specific mean differences. In all analyses, $P<0.05$ was taken to indicate statistical significance. All analyses were performed with a commercially available statistical package (Excel Statistics; SSRI Co., Ltd., Tokyo, Japan).

\section{Results}

\subsection{Experiment 1}

\subsubsection{Food Intake, Body Weight, and Liver Weights} Mean food intake for 3-day refeeding period, final body weight, and liver weight did not differ among the four groups (mean values: food intake, $17.6 \mathrm{~g}$ /day; final body weight, $205 \mathrm{~g}$; liver weight, $10.8 \mathrm{~g}$ [all dietary groups]). Neither dietary fat nor cholesterol influenced food intake, body weight, or liver weight. 


\subsubsection{Plasma Substrates}

Table 3 shows the plasma cholesterol and TG concentrations. The high-cholesterol diet caused the plasma total, free, and non HDL-cholesterol, and cholesteryl ester concentrations to increase significantly, whereas plasma HDL-cholesterol concentration decreased significantly in the beef tallow diet group.

In the corn oil diet group, the plasma total, free, and cholesteryl ester concentrations did not differ between the high-cholesterol and cholesterol-free diet groups. The plasma concentrations of HDL-cholesterol were significantly lower and those of non HDL-cholesterol and triglyceride (TG) were significantly higher in rats fed a high-cholesterol diet than in those fed a cholesterol-free diet in the corn oil diet group. The high-cholesterol diet significantly increased the ratio of total cholesterol per TG in the beef tallow diet group. High-cholesterol dietinduced hypercholesterolemia and hyperlipidemia were confirmed in beef tallow diet-fed rats compared to those fed corn oil fed.

\subsubsection{Liver Lipids}

Table 3 shows the liver cholesterol and TG contents. Liver total cholesterol, cholesteryl ester, and TG were significantly higher, whereas liver free cholesterol was lower in the high-cholesterol groups than in the cholesterol-free groups in both beef tallow and corn oil diet-fed rats.

\subsubsection{Fatty Acid Composition of Plasma Cholesteryl Ester}

Table 5 shows the fatty acid composition of plasma cholesteryl ester. The percentage of oleic acid was signifi- cantly higher, whereas that of linoleic acid was significantly lower in rats fed a beef tallow diet than in rats fed a corn oil diet in either the high-cholesterol or cholesterol-free group. The high-cholesterol diet increased the percentage of saturated fatty acids of plasma cholesteryl ester in the beef tallow diet groups. The percentage of arachidonic acid was significantly lower in the highcholesterol groups than in the cholesterol-free groups in both beef tallow diet- and corn oil diet-fed rats. In the high-cholesterol diet-fed rats, the percentage of arachidonic acid was significantly lower in the beef tallow diet group than in the corn oil diet group.

\subsection{Experiment 2}

\subsubsection{Food Intake, Body Weight, and Liver Weight}

Mean food intake for 3-day refeeding period, final body weight, and liver weight did not differ among the four groups (mean values: food intake, $15.8 \mathrm{~g} /$ day; final body weight, $210 \mathrm{~g}$; liver weight, $11.0 \mathrm{~g}$ [all dietary groups]). Neither dietary fat nor cholestyramine was influenced by food intake, body weigh, or liver weight.

\subsubsection{Plasma Substrates}

Table 4 shows the plasma cholesterol and TG concentrations. The dietary cholestyramine decreased plasma concentrations of total, free, HDL-, non HDL-cholesterol, and cholesteryl ester in both beef tallow and corn oil diet groups, but the differences were not significant. In rats fed the high-cholesterol-cholestyramine diet, the plasma non HDL-cholesterol concentration was significantly higher in the beef tallow diet group than in the corn oil diet group. The plasma TG concentration and ratio of

Table 3. Effect of dietary fats and cholesterol on plasma and liver components in rats under starvation-refeeding conditions (Experiment 1).

\begin{tabular}{|c|c|c|c|c|c|c|c|c|}
\hline \multicolumn{2}{|c|}{ Plasma } & Total Chol & Free Chol & Chol ester & HDL-Chol & Non HDL-Chol & TG & Total Chol/TG \\
\hline \multicolumn{2}{|c|}{ Groups } & $\mathrm{mg} / 100 \mathrm{ml}$ & $\mathrm{mg} / 100 \mathrm{ml}$ & $\mathrm{mg} / 100 \mathrm{ml}$ & $\mathrm{mg} / 100 \mathrm{ml}$ & $\mathrm{mg} / 100 \mathrm{ml}$ & $\mathrm{mg} / 100 \mathrm{ml}$ & \\
\hline \multirow[t]{2}{*}{ Beef tallow } & Chol & $226 \pm 55^{\mathrm{a}}$ & $38.7 \pm 10.3^{\mathrm{a}}$ & $187 \pm 45^{\mathrm{a}}$ & $17.8 \pm 6.4^{\mathrm{c}}$ & $208 \pm 61^{\mathrm{a}}$ & $102 \pm 23^{\mathrm{a}}$ & $2.42 \pm 1.28^{\mathrm{a}}$ \\
\hline & Con & $83 \pm 7^{\mathrm{b}}$ & $21.2 \pm 3.9^{\mathrm{b}}$ & $62 \pm 9^{\mathrm{b}}$ & $59.9 \pm 8.0^{\mathrm{a}}$ & $23 \pm 6^{c}$ & $128 \pm 33^{\mathrm{a}}$ & $0.69 \pm 0.21^{\mathrm{b}}$ \\
\hline \multirow[t]{2}{*}{ Corn oil } & Chol & $112 \pm 16^{\mathrm{b}}$ & $22.7 \pm 4.1^{\mathrm{b}}$ & $90 \pm 12^{\mathrm{b}}$ & $18.8 \pm 1.5^{\mathrm{c}}$ & $94 \pm 14^{b}$ & $123 \pm 44^{\mathrm{a}}$ & $1.00 \pm 0.33^{\mathrm{b}}$ \\
\hline & Con & $77 \pm 10^{b}$ & $16.5 \pm 2.0^{b}$ & $60 \pm 11^{\mathrm{b}}$ & $49.5 \pm 11.0^{\mathrm{b}}$ & $27 \pm 9^{c}$ & $60 \pm 23^{b}$ & $1.48 \pm 0.70^{\mathrm{ab}}$ \\
\hline \multicolumn{2}{|c|}{ Liver } & Total Chol & Free Chol & Chol ester & TG & & & \\
\hline \multicolumn{2}{|c|}{ Groups } & $\mathrm{mg} / \mathrm{g}$ tissue & $\mathrm{mg} / \mathrm{g}$ tissue & $\mathrm{mg} / \mathrm{g}$ tissue & $\mathrm{mg} / \mathrm{g}$ tissue & & & \\
\hline \multirow[t]{2}{*}{ Beef tallow } & Chol & $21.5 \pm 0.9^{\mathrm{a}}$ & $1.43 \pm 0.33^{\mathrm{c}}$ & $20.1 \pm 0.9^{\mathrm{a}}$ & $33.5 \pm 4.7^{\mathrm{a}}$ & & & \\
\hline & Con & $7.0 \pm 1.4^{\mathrm{b}}$ & $5.41 \pm 0.96^{\mathrm{a}}$ & $1.9 \pm 0.4^{\mathrm{a}}$ & $21.4 \pm 5.7^{\mathrm{b}}$ & & & \\
\hline \multirow[t]{2}{*}{ Corn oil } & Chol & $21.8 \pm 2.8^{\mathrm{a}}$ & $0.92 \pm 0.72^{\mathrm{c}}$ & $20.9 \pm 2.3^{\mathrm{a}}$ & $36.7 \pm 15.2^{\mathrm{a}}$ & & & \\
\hline & Con & $7.6 \pm 0.8^{\mathrm{b}}$ & $3.41 \pm 0.31^{\mathrm{b}}$ & $4.0 \pm 1.0^{\mathrm{b}}$ & $17.2 \pm 4.0^{\mathrm{b}}$ & & & \\
\hline
\end{tabular}

Values are means \pm SD for 5 rats. Means with different superscripts within a column are significantly different at $P<0.05$; Con, control; Chol, cholesterol; TG, triacylglycerol. 
Table 4. Effect of dietary fats and cholestyramine on plasma and liver components in rats under starvation-refeeding conditions (Experiment 2).

\begin{tabular}{|c|c|c|c|c|c|c|c|c|}
\hline \multicolumn{2}{|c|}{ Plasma } & Total Chol & Free Chol & Chol ester & HDL-Chol & Non HDL-Chol & TG & Total Chol/TG \\
\hline \multicolumn{2}{|c|}{ Groups } & $\mathrm{mg} / 100 \mathrm{ml}$ & $\mathrm{mg} / 100 \mathrm{ml}$ & $\mathrm{mg} / 100 \mathrm{ml}$ & $\mathrm{mg} / 100 \mathrm{ml}$ & $\mathrm{mg} / 100 \mathrm{ml}$ & $\mathrm{mg} / 100 \mathrm{ml}$ & \\
\hline \multirow[t]{2}{*}{ Beef tallow } & Chol-Cm & $109 \pm 32^{\mathrm{ab}}$ & $21.7 \pm 4.5^{\mathrm{ab}}$ & $87 \pm 27^{\mathrm{b}}$ & $33.7 \pm 5.0^{\mathrm{a}}$ & $75 \pm 31^{a}$ & $138 \pm 45$ & $0.89 \pm 0.40$ \\
\hline & Chol & $223 \pm 136^{\mathrm{a}}$ & $38.1 \pm 20.7^{\mathrm{a}}$ & $185 \pm 116^{\mathrm{a}}$ & $20.4 \pm 4.6^{\mathrm{c}}$ & $203 \pm 140^{\mathrm{a}}$ & $94 \pm 32$ & $2.56 \pm 1.90$ \\
\hline \multirow[t]{2}{*}{ Corn oil } & Chol-Cm & $70 \pm 9^{b}$ & $15.0 \pm 3.5^{\mathrm{b}}$ & $55 \pm 8^{\mathrm{b}}$ & $31.1 \pm 5.1^{\mathrm{ab}}$ & $39 \pm 11^{\mathrm{b}}$ & $80 \pm 33$ & $0.96 \pm 0.30$ \\
\hline & Chol & $130 \pm 29^{\mathrm{ab}}$ & $24.6 \pm 6.6^{\mathrm{ab}}$ & $105 \pm 22^{\mathrm{ab}}$ & $20.7 \pm 3.5^{\mathrm{c}}$ & $109 \pm 31^{\mathrm{ab}}$ & $98 \pm 30$ & $1.38 \pm 0.30$ \\
\hline \multicolumn{2}{|c|}{ Liver } & Total Chol & Free Chol & Chol ester & $\mathrm{TG}$ & & & \\
\hline \multicolumn{2}{|c|}{ Groups } & $\mathrm{mg} / \mathrm{g}$ tissue & $\mathrm{mg} / \mathrm{g}$ tissue & $\mathrm{mg} / \mathrm{g}$ tissue & $\mathrm{mg} / \mathrm{g}$ tissue & & & \\
\hline \multirow[t]{2}{*}{ Beef tallow } & Chol-Cm & $8.6 \pm 1.9^{\mathrm{c}}$ & $4.5 \pm 1.1$ & $4.2 \pm 0.9^{\mathrm{c}}$ & $14.4 \pm 5.9$ & & & \\
\hline & Chol & $22.4 \pm 3.6^{\mathrm{a}}$ & $4.1 \pm 2.7$ & $18.3 \pm 3.3^{\mathrm{a}}$ & $31.5 \pm 18.0$ & & & \\
\hline \multirow[t]{2}{*}{ Corn oil } & Chol-Cm & $13.0 \pm 2.8^{\mathrm{b}}$ & $5.5 \pm 1.7$ & $7.5 \pm 1.4^{\mathrm{b}}$ & $21.7 \pm 10.0$ & & & \\
\hline & Chol & $23.1 \pm 2.8^{\mathrm{a}}$ & $4.1 \pm 1.8$ & $19.4 \pm 1.8^{\mathrm{a}}$ & $26.6 \pm 6.3$ & & & \\
\hline
\end{tabular}

Values are means \pm SD for 5 rats. Means with different superscripts within a column are significantly different at $P<0.05$; Cm, cholestyramine; Chol, cholesterol; TG, triacylglycerol.

Table 5. Fatty acid composition of plasma cholesteryl ester in rats under starvation-refeeding conditions (Experiments 1 and 2).

\begin{tabular}{|c|c|c|c|c|c|c|c|c|c|}
\hline \multirow{2}{*}{\multicolumn{2}{|c|}{ Groups }} & $14: 0$ & $16: 0$ & $16: 1$ & $18: 0$ & $18: 1$ & $18: 2$ & $20: 4$ & $22: 6$ \\
\hline & & \multicolumn{8}{|c|}{$\mathrm{g} / 100 \mathrm{~g}$ total fatty acid } \\
\hline \multicolumn{10}{|c|}{ Experiment 1} \\
\hline \multirow[t]{2}{*}{ Beef tallow } & Chol & $0.4 \pm 0.3$ & $14.3 \pm 4.2^{\mathrm{a}}$ & $7.7 \pm 1.4^{\mathrm{a}}$ & $3.8 \pm 1.4^{\mathrm{a}}$ & $60.3 \pm 8.2^{\mathrm{a}}$ & $4.3 \pm 1.3^{\mathrm{d}}$ & $9.6 \pm 4.9^{\mathrm{c}}$ & $1.2 \pm 0.8$ \\
\hline & Con & $0.5 \pm 0.2$ & $6.5 \pm 1.7^{b}$ & $3.6 \pm 1.0^{\mathrm{b}}$ & $0.7 \pm 0.6^{\mathrm{b}}$ & $18.6 \pm 2.6^{\mathrm{c}}$ & $11.9 \pm 2.2^{\mathrm{c}}$ & $55.6 \pm 4.1^{\mathrm{a}}$ & $2.2 \pm 1.0$ \\
\hline \multirow[t]{2}{*}{ Corn oil } & Chol & $0.3 \pm 0.1$ & $5.6 \pm 0.1^{\mathrm{b}}$ & $2.4 \pm 0.8^{\mathrm{b}}$ & $0.6 \pm 0.4^{\mathrm{b}}$ & $30.0 \pm 2.2 b$ & $23.4 \pm 0.8^{\mathrm{a}}$ & $27.0 \pm 4.4^{\mathrm{b}}$ & $0.8 \pm 0.5$ \\
\hline & Con & $0.3 \pm 0.1$ & $5.1 \pm 0.1^{\mathrm{b}}$ & $0.7 \pm 0.2^{\mathrm{c}}$ & $0.7 \pm 0.4^{\mathrm{b}}$ & $5.1 \pm 0.9^{d}$ & $21.9 \pm 1.5^{\mathrm{b}}$ & $60.3 \pm 2.7^{\mathrm{a}}$ & $1.9 \pm 0.3$ \\
\hline \multicolumn{10}{|c|}{ Experiment 2} \\
\hline \multirow[t]{2}{*}{ Beef tallow } & Chol-Cm & $0.5 \pm 0.1$ & $8.6 \pm 0.9^{b}$ & $5.4 \pm 0.9^{b}$ & $2.0 \pm 0.7^{\mathrm{b}}$ & $35.7 \pm 9.2^{\mathrm{b}}$ & $8.2 \pm 1.6^{\mathrm{b}}$ & $33.0 \pm 8.4^{\mathrm{a}}$ & $0.4 \pm 0.6^{\mathrm{b}}$ \\
\hline & Chol & $0.4 \pm 0.1$ & $13.3 \pm 2.4^{\mathrm{a}}$ & $7.1 \pm 1.9^{\mathrm{a}}$ & $3.7 \pm 0.5^{\mathrm{a}}$ & $55.6 \pm 6.2^{\mathrm{a}}$ & $4.9 \pm 2.3^{\mathrm{b}}$ & $11.2 \pm 6.3^{\mathrm{b}}$ & $0.2 \pm 0.4^{b}$ \\
\hline \multirow[t]{2}{*}{ Corn oil } & Chol-Cm & $0.4 \pm 0.2$ & $7.0 \pm 1.9^{\mathrm{b}}$ & $1.4 \pm 0.4^{\mathrm{c}}$ & $0.9 \pm 0.2^{\mathrm{bc}}$ & $19.0 \pm 4.1^{\mathrm{c}}$ & $26.9 \pm 1.6^{\mathrm{a}}$ & $38.7 \pm 7.9^{\mathrm{a}}$ & $2.2 \pm 2.7^{a}$ \\
\hline & Chol & $0.3 \pm 0.1$ & $7.3 \pm 1.7^{\mathrm{b}}$ & $2.9 \pm 0.4^{\mathrm{c}}$ & $0.6 \pm 0.3^{\mathrm{c}}$ & $41.7 \pm 9.2^{\mathrm{b}}$ & $28.7 \pm 4.2^{\mathrm{a}}$ & $14.6 \pm 9.9^{\mathrm{b}}$ & $0.9 \pm 0.4$ \\
\hline
\end{tabular}

Values are means $\pm \mathrm{SD}$ for 5 rats. Means with different superscripts within a column are significantly different at $P<0.05$. Con, control; Chol, cholesterol; Cm, cholestyramine.

total cholesterol per TG did not differ among the four groups.

\subsubsection{Liver Lipids}

Table 4 shows the liver cholesterol and TG contents. The dietary cholestyramine significantly decreased liver total cholesterol and cholesteryl ester contents in the both beef tallow and corn oil diet groups. In rats fed the high-cholesterol-cholestyramine diet, liver total cholesterol and cholesteryl ester contents were significantly lower in the beef tallow diet group than in the corn oil diet group. The liver free cholesterol and TG did not differ among the four diet groups.

\subsubsection{Fatty Acid Composition of Plasma Cholesteryl Ester}

Table 5 shows the fatty acid composition of plasma cholesteryl ester. In rats fed high-cholesterol diet, the percentages of myristic, palmitic, palmitoleic, and stearic acids were significantly higher, whereas those of linoleic 
and docosahexaenoic acids were significantly lower in the beef tallow diet group than in the corn oil diet group.

The dietary cholestyramine significantly decreased the percentage of oleic acid and significantly increased that of arachidonic acid in both beef tallow and corn oil diet groups.

\section{Discussion}

We previously suggested that starvation-refeeding increased the plasma cholesterol concentration in rats fed a high-fat/high-cholesterol diet [16]. As starvation-refeeding may enhance the response to dietary fats, we decided it to adopt this method. In the present study, we found that dietary supplemental $1 \%$ cholesterol increased plasma cholesterol concentration in rats fed a beef tallow diet compared to rats fed a corn oil diet under the starvetion-refeeding conditions. In particular, the increase of cholesteryl ester concentration (i.e., it increased the cholesteryl ester/free cholesterol ratio) indicated that a beef tallow diet may influence the synthesis of hepatic acylCoA: cholesterol acyltransferase (ACAT; EC2.3.2.26) [27]. ACAT, an integrated membrane enzyme, is involved in regulating intracellular cholesterol homeostasis by catalyzing formation of cholesteryl ester from free cholesterol and long-chain acyl-CoA. A high-cholesterol diet is associated with increased hepatic microsomal ACAT activity [28]. DeWitt et al. [29] suggested that stimulation of ACAT activity was only observed with the addition of oleic acid, but not with palmitic, stearic, or linoleic acids in vitro. On the other hand, lecithin cholesterol acyltransferase (LCAT; EC2.3.1.43) is known as another important enzyme for plasma cholesteryl ester metabolism [30]. LCAT is present in higher concentrations in plasma than in other tissues, and mainly transfers fatty acids from the 2-position of phospholipids to cholesterol. The LCAT reaction is a physiologically important source of plasma cholesteryl esters [30]. Marcel et al. [31] reported that substrate specificity of LCAT to arachidonic acid was higher than saturated and monounsaturated fatty acids. In addition, Romoijn et al. [32] suggested that a linoleic acid-enriched diet increases serum cholesterol esterification by LCAT in meal-fed rats. In the present findings, the percentage of oleic acid in plasma cholesteryl ester was higher, whereas those of arachidonic and linoleic acids were lower in rats fed a beef tallow diet than in rats fed a corn oil diet, especially when $1 \%$ cholesterol was added to diet. We observed a correlation between plasma cholesteryl ester concentration and the percentage of oleic acid in plasma cholesteryl ester $(r=0.93, P<0.05)$, whereas a negative correlation was observed between plasma cholesteryl ester concentration and the percentages of arachidonic and linoleic acids in plasma cholesteryl ester $(r=0.83, P<$
$0.05 ; r=0.66, P<0.05$ respectively). These results suggest that the reactions of ACAT and LCAT influenced by fatty acid composition of dietary fats or by a high-cholesterol diet under starvation-refeeding conditions, resulted in higher plasma cholesterol concentration in rats fed a beef tallow diet.

There is evidence to suggest that dietary fatty acids affect LDL cholesterol levels via several different mechanisms, including effects on whole-animal sterol balance and LDL production or turnover [33]; however, modulation of LDL receptor-mediated uptake of LDL is thought to be the primary pathway regulating plasma cholesterol levels. Studies in humans [34] and animal models [35] have shown that changes in plasma LDL cholesterol as a result of dietary fatty acid modification are associated with changes in its fractional catabolic rate (FCR). Alterations in the FCR are presumably mediated via changes in the receptor-mediated uptake of LDL particles by the liver. Consequently, there is considerable interest in studying fatty acid regulation of the LDL receptor. Mustad et al. [36] reported that dietary linoleic acid increases and palmitic acid decreases hepatic LDL receptor protein and mRNA abundance in young pigs. In the present study, linoleic and palmitic acids were the main elements composing corn oil and beef tallow respectively. In the high-cholesterol diet groups, plasma non-HDL cholesterol was significantly higher in rats fed a beef tallow diet than in rats fed a corn oil diet. Our results at least partially support previous findings.

Ultimately, cholesterol must enter the liver and be excreted in the bile acids [37]. Approximately half of the cholesterol fed or synthesized is excreted in the feces after being conversed to bile acids. Much of the cholesterol secreted in the bile is reabsorbed, and it is believed that at least some of the cholesterol that serves as a precursor for the fecal sterols is derived from the intestinal mucosa. A large fraction of the bile salts excreted is reabsorbed into the portal circulation, taken up by the liver, and re-excreted in the bile, a cycle known as enterohepatic circulation [38]. Unfortunately, in our experiment we did not determine the fecal excretion of cholesterol and bile salts. However, dietary cholestyramine markedly decreased plasma and liver cholesterol levels in both rats fed a beef tallow diet and rats fed a corn oil diet. Cholestyramine, a resin that strongly binds bile acids, is used as a hypolipidemic drug [39]. Cholestyramine is considered to lower plasma cholesterol levels by inhibiting the enterohepatic circulation of bile acids. In the present study, plasma and liver cholesterol levels were higher in the beef tallow diet group than in the corn oil diet group even if cholestyramine was added to those diets. These results suggested that the cholesterol-lowering effect of dietary corn oil may not be due only to reabsorption of 
bile acids. The present study suggests that high-fat diets consisting of different fats at least in partially affect cholesterol metabolism under the starvation-refeeding conditions, but further detailed studies are required to confirm and clarify the mechanism.

\section{REFERENCES}

[1] Z. Kochan, J. Karbowska and J. Swierczynski, "Unusual Increase of Lipogenesis in Rat White Adipose Tissue after Multiple Cyclesof Starvation-Refeeding," Metabolism, Vol. 46, No. 1, 1997, pp. 10-17. doi:10.1016/S0026-0495(97)90160-8

[2] H. M. Tepperman and J. Tepperman, "The Hexose Monophosphate Shunt and Adaptive Hyperlipogenesis," Diabetes, Vol. 15, No. 7, 1958, pp. 478-485.

[3] J. Karbowska, Z. Kochan and J. Swierczynski, "Increase of Lipogenic Enzyme MRNA Levels in Rat White Adipose Tissue after Multiple Cycles of Starvation-Refeeding," Metabolism, Vol. 50, No. 6, 2001, pp. 734-738. doi:10.1053/meta.2001.23309

[4] Z. Kochan, J. E. Goyke, Karbowska, J. E. Slominska and Swierczynski, "The Decrease of Rat Postprandial Plasma Triacylglycerol Concentration after Multiple Cycles of Starvation-Refeeding," Hormone and Metabolic Research, Vol. 33, No. 1, 2001, pp. 26-29. doi:10.1055/s-2001-12622

[5] S. J. Wakil, J. K. Stoops and V. C. Joshi, "Fatty Acid Synthesis and Its Regulation," Annual Review of Biochemistry, Vol. 52, 1985, pp. 537-579. doi:10.1146/annurev.bi.52.070183.002541

[6] R. Wurdeman, C. D. Berdanier and R. B. Tobin, "Enzyme Overshoot in Starved-Refed Rats: Role of the Adrenal Glucocorticoid," Journal of Nutrition, Vol. 108, No. 9, 1978, pp. 1457-1461.

[7] C. D. Berdanier and D. Shubeck, "Interaction of Glucocorticoid Andinsulin in the Responses of Rats to Starvation-Refeeding," Journal of Nutrition, Vol. 109, No. 10, 1979, pp. 1766-1771.

[8] V. M. Lee, B. Szepesi and R. J. Hansen, "Gender-Linked Differences in Dietary Induction of Hepatic Glucose6-Phosphate Dehydrogenase and Malic Enzyme," Journal of Nutrition, Vol. 116, No. 8, 1986, pp. 1547-1554.

[9] R. L. Baldwin, M. Ronning, C. Radanovics and G. Plange, "Effect of Carbohydrate and Fat Intakes upon the Activities of Several Liver Enzymes in Rats, Guinea Piglets, Piglets and Calves," Journal of Nutrition, Vol. 90, No. 1, 1966, pp. 45-55.

[10] C. S. Nace and B. Szepesi, "Dietary Fatty Acids and the Control of Glucose-6-Phosphate Dehydrogenase and Malic Enzyme in the Starved Refed Rats," Journal of Nutrition, Vol. 106, No. 2, 1976, pp. 285-291.

[11] U. A. Siddiqui, T. Goldflam and A. G. Goodridge, "Nutritional and Hormonal Regulation of the Translatable Levels of Malic Enzyme and Albumin MRNA in Avian Liver Cells in Vivo and in Culture," Journal of Biological Chemistry, Vol. 256, No. 9, 1981, pp. 4544-4550.
[12] D. W. Back, S. B. Wilson, S. M. Morris Jr. and A. G. Goodridge, "Hormonal Regulation of Lipogenic Enzymes in Chick Embryo Hepatocytes in Culture. Thyroid Hormone and Glucagon Regulate Malic Enzyme MRNA Level at Post-transcriptional Steps," Journal of Biological Chemistry, Vol. 261, No. 27, 1986, pp. 12555-12561.

[13] S. B. Wilson, D. W. Back, Morris Jr., J. Swierczynski and A. G. Goodridge, "Hormonal Regulation of Lipogenic Enzymes in Chick Embryo Hepatocytes in Culture. Expression of the Fatty Acid Synthase Gene is Regulated at Both Translational and Pretranslational Steps," Journal of Biological Chemistry, Vol. 261, No. 32, 1986, pp. 15183-15185.

[14] G. H. Rothblat and D. Kritchevsky, "The Metabolism of Free and Esterified Cholesterol in Tissue Culture Cells: A Review," Experimental and Molecular Pathology, Vol. 8, No. 3, 1968, pp. 314-329. doi:10.1016/S0014-4800(68)80003-6

[15] C. R. Pullinger and G. F. Gibbons, "Effects of Hormones and Pyruvate on the Rates of Secretion of VeryLow-Density Lipoprotein Triacylglycerol and Cholesterol by Rat Hepatocytes," Biochimica et Biophysica Acta, Vol. 833, No. 1, 1985, pp. 44-51.

[16] R. Inai and T. Matsuo, "Effect of Starvation-Refeeding Status on Cholesterol Metabolism in Rats Fed HighCholesterol Diet," Food and Nutrition Sciences, Vol. 2, No. 2, 2011, pp. 118-123. doi:10.4236/fns.2011.22016

[17] D. M. Hegsted, R. B. McGandy, M. Myers and F. J. Stare, "Quantitative Effects of Dietary Fat on Serum Cholesterol in Man," American Journal of Clinical Nutrition, Vol. 17, No. 5, 1965, pp. 281-295.

[18] A. Keys, J. T. Anderson and F. Grande, "Serum Cholesterol Response to Changes in the Diet," Metabolism, Vol. 14, No. 7, 1965, pp. 776-787. doi:10.1016/0026-0495(65)90004-1

[19] J. T. Anderson, F. Grande and A. Keys, "Independence of the Effects of Cholesterol and Degree of Saturation of the Fat in the Diet on Serum Cholesterol in Man," American Journal of Clinical Nutrition, Vol. 29, No. 11, 1976, pp. 1184-1189.

[20] G. Schonfeld, W. Patsh, L. L. Rudel, C. Nelson, M. Epstein and R. E. Olson, "Effect of Dietary Cholesterol and Fatty Acids on Plasma Lipoproteins," Journal of Clinical Investigation, Vol. 69, No. 5, 1982, pp. 1072-1080. doi:10.1172/JCI110542

[21] S. M. Goodnight Jr., W. S. Harris, W. E. Connor and D. R. Illingworth, "Polyunsaturated Fatty Acids, Hyperlipidemia, and Thrombosis," Arteriosclerosis, Vol. 2, No. 2, 1982, pp. 87-113. doi:10.1161/01.ATV.2.2.87

[22] Q. R. Rogersm and A. E. Harper, "Amino Acid Diets and Maximal Growth in the Rat," Journal of Nutrition, Vol. 87, No. 3, 1965, pp. 267-273.

[23] J. Folch, M. Lees and G. H. Sloane-Standley, "A Simple Method for the Isolation and Purification of Total Lipids from Animal Tissues," Journal of Biological Chemistry, Vol. 226, No. 1, 1957, pp. 497-509.

[24] B. Zak, "Simple Rapid Microtechnic for Serum Total 
Cholesterol," American Journal of Clinical Pathology, Vol. 27, No. 5, 1957, pp. 583-588.

[25] B. E. Cham, J. J. Hurwood, B. R. Knowles and L. W. Powell, "Rapid, Sensitive Method for the Separation of Free Cholesterol from Ester Cholesterol," Clinica Chimica Acta, Vol. 49, No. 1, 1973, pp. 109-113. doi:10.1016/0009-8981(73)90350-1

[26] C. Alling, L. Svennerholm and J. Tichy, "Fatty Acid Composition of Serum Cholesteryl Ester Fractions is Isolated by Thin-Layer Chromatography," Journal of Chromatography, Vol. 34, No. 3, 1968, pp. 413-415. doi:10.1016/0021-9673(68)80080-9

[27] K. E. Suckling and E. F. Stange, "Role of Acyl-CoA: Cholesterol Acyltransferase in Cellular Cholesterol Metabolism," Journal of Lipid Research, Vol. 26, No. 6, 1985, pp. 647-671.

[28] D. Sun, M. L. Fernandez, E. C. K. Lin and D. J. McNamara, "Regulation of Guinea Pig Hepatic Acyl-CoA: Cholesterol Acyltransferase Activity by Dietary Fat Saturation and Cholesterol," Journal of Nutritional Biochemistry, Vol. 10, No. 3, 1999, pp. 172-180. doi:10.1016/S0955-2863(98)00097-7

[29] D. S. Goodman, D. Deykin and T. Shiratori, "The Formation of Cholesterol Ester with Rat Liver Enzyme," Journal of Biological Chemistry, Vol. 239, No. 5, 1964, pp. 1335-1345.

[30] J. A. Glomset, "The Plasma Lecithin: Cholesterol Acyltransferase Reaction," Journal of Lipid Research, Vol. 9, No. 2, 1968, pp. 155-167.

[31] Y. L. Marcel, "Lecithin: Cholesterol Acyltransferase and Intravascular Cholesterol Transport," Advances in Lipid Research, Vol. 19, No. 2, 1982, pp. 85-136.

[32] D. Romijn, S. A. Wiseman, L. M. Scheek, N. J. de Fouw and A. van Tol, "A Linoleic Acid Enriched Diet Increases
Serum Cholesterol Esterification by Lecithin: Cholesterol Acyltransferase in Meal-Fed Rats," Annals of Nutrition and Metabolism, Vol. 42, No. 4, 1998, pp. 244-250. doi: $10.1159 / 000012740$

[33] S. M. Grundy and M. A. Denke, "Dietary Influences on Serum Lipids and Lipoproteins," Journal of Lipid Research, Vol. 31, No. 7, 1990, pp. 1149-1172.

[34] J. Shepherd, C. J. Packard, S. M. Grandy, D. Yeshurun, A. M. Gotto and O. D. Taunton, "Effects of Low Density Lipoproteins in Man," Journal of Lipid Research, Vol. 21, No. 1, 1980, pp. 91-99.

[35] M. L. Fernandez and D. J. McNamara, "Regulation of Dietary Cholesterol Metabolism in Guinea Pigs Mediated by Dietary Fat Quality and Quantity," Journal of Nutrition, Vol. 121, No. 1, 1991, pp. 97-109.

[36] V. A. Mustad, J. L. Ellsworth, A. D. Cooper, P. M. Kris-Etherton and T. D. Etherton, "Dietary Linoleic Acid Increases and Palmitic Acid Decreases Hepatic LDL Receptor Protein and MRNA Abundance in Young Pig," Journal of Lipid Research, Vol. 37, No. 11, 1996, pp. 2310-2323.

[37] T. G. Cole, B. Pfleger and O. Hitchins, "Effects of High Cholesterol High Fat Diet on Plasma Lipoproteins in Familial Hypercholesterolemia," Metabolism, Vol. 34, No. 5, 1985, pp. 486-493. doi:10.1016/0026-0495(85)90216-1

[38] J. B. Kane and R. J. Havel, "Treatment of Hyper Cholesterolemia," Annual Reviews of Medicine, Vol. 37, 1986, pp. 427-434. doi:10.1146/annurev.me.37.020186.002235

[39] S. Shibata, K. Hayakawa, Y. Egashira and H. Sanada, "Role of Nuclear Receptors in the up-Regulation of Hepatic Cholesterol $7 \alpha$-Hydroxylase by Cholestyramine in Rats," Life Science, Vol. 80, No. 6, 2006, pp. 546-553. doi:10.1016/j.1fs.2006.10.003 